\title{
Ascorbic acid in the gonads of North Sea dab (Limanda limanda) during the reproductive cycle
}

\author{
Reinhard Saborowski, Jean-François Koprivnjak, Mitchell M. Sisak, \\ Gerrit Sahling, Friedrich Buchholz, Ken R. Lum, and Rolf Schneider
}

\begin{abstract}
Total ascorbic acid was measured in the gonads of North Sea dab (Limanda limanda) throughout one reproductive cycle. In the ovaries, the concentration of ascorbate began to increase during the resting period in summer and reached maximum values of $400 \mu \mathrm{g} \cdot \mathrm{g}$ fresh weight $(\mathrm{fw})^{-1}$ at the onset of ovary maturation in fall. Concentrations declined rapidly towards the spawning period in spring and reached the lowest values of $80-100 \mu \mathrm{g} \cdot \mathrm{g} \mathrm{fw}^{-1}$. The maximum deposition of ascorbate in the ovaries amounted to $2.5 \mathrm{mg} \cdot \mathrm{organ}^{-1}$ and occurred in late winter, corresponding to the beginning of the spawning period. In the testes, ascorbate concentrations were lower than in the ovaries, reaching a maximum of $170 \mu \mathrm{g} \cdot \mathrm{g} \mathrm{fw}{ }^{-1}$ in early fall. The lowest values of $20-60 \mu \mathrm{g} \cdot \mathrm{g} \mathrm{fw}^{-1}$ appeared in winter and spring. In the testes the highest deposition of ascorbate amounted to $110 \mu \mathrm{g} \cdot \mathrm{organ}^{-1}$ and appeared at the beginning of maturation. The sexual differences and seasonal variations are discussed in relation to the reproductive biology of dab.

Résumé : L'acide ascorbique total a été mesuré dans les gonades des poissons Limande (Limanda limanda) de la mer du nord durant un cycle reproductif complet. Dans les ovaires les concentrations de l'acide ascorbique total commencent à augmenter durant la période de repos (été), et atteignent des valeurs maximales de $400 \mu \mathrm{g} \cdot \mathrm{g}$ poids frais (pf) ${ }^{-1}$ durant l'automne; c'est à dire au début de la croissance des ovaires. Au printemps, les concentrations ont chuté rapidement avant la période de fraye, et ont atteint des concentrations minimales de 80 à $100 \mu \mathrm{g} \cdot \mathrm{g} \mathrm{pf}^{-1}$. Vers la fin de l'hiver, la déposition maximale de l'acide ascorbique était de $2.5 \mathrm{mg} \cdot$ organe $^{-1}$, correspondant au début de la période de fraye. Au début de l'automne, dans les testicules, les concentrations de l'acide ascorbique total étaient moins que dans les ovaires atteignant une valeur maximale de $170 \mu \mathrm{g} \cdot \mathrm{g} \mathrm{pf^{-1 }}$. En hiver et au printemps, des concentrations minimales de 20 à $60 \mu \mathrm{g} \cdot \mathrm{g} \mathrm{pf}^{-1}$ ont été atteintes. Au début de la maturation, la déposition d'acide ascorbique dans les testicules était de $110 \mu \mathrm{g} \cdot$ organe $^{-1}$. La différence sexuelle et les cycles saisonièrs sont mis en relation avec la biologie de reproduction du limande.
\end{abstract}

\section{Introduction}

In teleost fish, ascorbic acid is an essential vitamin that is involved in a number of physiological processes such as collagen formation, bone formation, and wound healing (summarized by Halver 1989). Feeding an ascorbate-deficient diet to young carp (Cirrhina mrigala) over a long period results in serious scoliosis and increased mortality (Mahajan and Agrawal 1980). As a reducing agent, ascorbate is also involved in enzymatic processes and, in concert with vitamin E, constitutes a significant part of the intracellular oxidant defense system (reviewed by Chow 1991).

Furthermore, ascorbate plays an important role in the reproductive physiology of fish. High concentrations have been measured in gonads, eggs, and fry of different fish species (Dabrowski 1977; Sandnes and Braekkan 1981; Dabrowski 1991; Hapette et al. 1991; Dabrowski and Blom 1994). Ascorbate

Received September 15, 1995. Accepted May 1, 1997.

$\mathrm{J} 13082$

R. Saborowski, ${ }^{1}$ G. Sahling, and F. Buchholz. Biologische Anstalt Helgoland (Meeresstation), D-27483 Helgoland, Germany.

J-F. Koprivnjak, M.M. Sisak, and K.R. Lum. Environment Canada, Centre St. Laurent, 105 McGill St., Montreal,

QC H2Y 2E7, Canada.

R. Schneider. Institut für Ostseeforschung, Seestrasse 15, D-18119 Rostock-Warnemünde, Germany.

1 Author to whom all correspondence should be addressed. e-mail: Rsaborow@mail.desy.de deficiency causes an impaired hatching rate in rainbow trout (Oncorhynchus mykiss, formerly Salmo gairdneri) eggs (Sandnes et al. 1984), and a high ascorbate requirement in embryonic development has been demonstrated by Sato et al. (1987).

However, the relationship between reproductive periods and ascorbate levels as well as the seasonal course of ascorbate deposition into the reproductive organs has not been investigated in detail. The purpose of the present work was to study the seasonal variations of ascorbate levels in the gonads of a marine flatfish species and to relate these to the season and the phases of the reproductive cycle. Dab (Limanda limanda) were chosen for this investigation because this species is characterized by a high fecundity. The reproductive cycle of dab and its spawning habits are well defined (Bohl 1957). Histological changes in the ovaries and testes during the reproductive cycle are described by Htun-Han (1978a, 1978b).

Furthermore, dab have been used as a model organism in several ecotoxycological investigations (e.g., Stebbing et al. 1992) including oxidant protection. In this respect, this work was also aimed at contributing basic information on the natural levels and the seasonal variability of ascorbate, an essential antioxidant.

\section{Materials and methods}

Sampling

Dab were caught at a permanent station northwest of Helgoland in the southern North Sea $\left(54^{\circ} 15^{\prime} \mathrm{N}, 7^{\circ} 45^{\prime} \mathrm{E}\right)$. Sampling was carried out with the research vessel FK Uthörn by bottom trawling every 4-6 weeks. 
Table 1. Sampling dates, numbers of samples, GSIs (means $\pm 95 \% \mathrm{CI}$ ), and reproductive periods of dab.

\begin{tabular}{|c|c|c|c|c|c|}
\hline \multirow[b]{2}{*}{ Date } & \multicolumn{2}{|r|}{ Females } & \multicolumn{2}{|r|}{ Males } & \multirow{2}{*}{$\begin{array}{l}\text { Reproductive } \\
\text { period }\end{array}$} \\
\hline & $n$ & GSI & $n$ & GSI & \\
\hline Jan. 28, 1993 & 14 & $12.81 \pm 3.59 a b$ & 11 & $1.51 \pm 0.32 b c$ & Prespawning \\
\hline Feb. 16, 1993 & 12 & $13.55 \pm 3.28 \mathrm{a}$ & 12 & $1.30 \pm 0.18 b c$ & Spawning \\
\hline Mar. 18, 1993 & 12 & $11.64 \pm 1.62 a b$ & 12 & $1.00 \pm 0.17 c$ & Spawning \\
\hline Apr. 7, 1993 & 12 & $6.28 \pm 2.49 c$ & 12 & $0.67 \pm 0.10 d$ & Spawning \\
\hline May 14, 1993 & 12 & $6.43 \pm 1.88 c$ & 12 & $0.29 \pm 0.06$ ef & Postspawning \\
\hline June 14,1993 & 12 & $1.77 \pm 0.49 \mathrm{de}$ & 12 & $0.19 \pm 0.08$ ef & Postspawning \\
\hline July 16, 1993 & 11 & $1.00 \pm 0.18$ ef & 12 & $0.17 \pm 0.04 f$ & Resting \\
\hline Aug. 27, 1993 & 11 & $0.98 \pm 0.10 e f$ & 13 & $0.28 \pm 0.14$ ef & Resting \\
\hline Sept. 22, 1993 & 13 & $1.00 \pm 0.12$ ef & 11 & $0.42 \pm 0.19 e$ & Resting \\
\hline Oct. 14,1993 & 12 & $1.31 \pm 0.20 e$ & 12 & $1.56 \pm 0.37 b c$ & Prespawning \\
\hline Nov. 16, 1993 & 12 & $3.19 \pm 0.80 d$ & 12 & $1.84 \pm 0.29 b$ & Prespawning \\
\hline Jan. 4, 1994 & 12 & $8.48 \pm 2.07 b c$ & 8 & $2.66 \pm 0.86 a$ & Prespawning \\
\hline Feb. 10, 1994 & 12 & $16.33 \pm 3.52 a$ & 6 & $1.38 \pm 0.30 b c$ & Spawning \\
\hline Mar. 17, 1994 & 12 & $12.47 \pm 2.23 a b$ & 8 & $1.49 \pm 0.34 b c$ & Spawning \\
\hline
\end{tabular}

Note: GSIs of sampling dates followed by same letter are not significantly different $(p<0.05$, ANOVA on square root transformed data).

For this study, samples taken between January 1993 and March 1994 (Table 1), covering an entire reproductive cycle, were analyzed.

Specimens between 18 and $20 \mathrm{~cm}$ long were killed with a blow to the head and organs were excised. During the resting period and early prespawning period from May to November the entire gonads were dissected. When ovaries were large during the prespawning and spawning period (December-April), representative pieces from the cranial part of the ovaries were dissected. The samples were shockfrozen and stored at $-80^{\circ} \mathrm{C}$ until analysis.

The gonad weight was normalized for the eviscerated carcass weight which was defined as total weight minus the weight of the intestines (gonads, liver, stomach, and gut) and expressed as gonadosomatic index $(\mathrm{GSI})=\operatorname{gonad}$ weight $\cdot 100 \cdot$ carcass weight $^{-1}$.

\section{Ascorbate determination}

Total ascorbate was determined colorimetrically after Carr et al. (1983) with the following modifications. The assay was adapted for the use in microplates. Gonad tissue $(50-150 \mathrm{mg}$ ) was homogenized in $1 \mathrm{~mL}$ of deproteinizing buffer (5\% trichloroacetic acid (TCA) in $250 \mathrm{mM} \mathrm{HClO}_{4}$ ) with an Ultraturrax blender (Janke \& Kunkel T25, $\mathrm{S} 25 \mathrm{C} 8 \mathrm{G})$ for $3 \times 5 \mathrm{~s}$ at $20000 \mathrm{rpm}$. The homogenates were centrifuged for $15 \mathrm{~min}$ at $15000 \times g\left(4^{\circ} \mathrm{C}\right)$ and the supernatants were used for analysis. Blanks were prepared by heating $200 \mu \mathrm{L}$ of the supernatant at $90^{\circ} \mathrm{C}$ for $2 \mathrm{~h}$ to hydrolyze ascorbate. For the determination, $50 \mu \mathrm{L}$ of the supernatant was incubated in a microplate $(8 \times 12$ wells $)$ at room temperature for $1 \mathrm{~h}$ with $10 \mu \mathrm{L}$ of 2,6-dichlorophenolindophenol (DCIP, Sigma D 1878, 0.2\% in water). Blanks were placed in the microplate and treated with DCIP like the samples. In the following incubation step, $50 \mu \mathrm{L}$ of 2,4-dinitrophenylhydrazine (Sigma D 2630, 2\% in $12 \mathrm{M} \mathrm{H}_{2} \mathrm{SO}_{4}$ ) and $50 \mu \mathrm{L}$ of thiourea reagent (Sigma T 7875, 2\% in 5\% metaphosphoric acid) were added. The plate was covered with parafilm and incubated for $3 \mathrm{~h}$ at $60^{\circ} \mathrm{C}$. Thereafter, $100 \mu \mathrm{L}$ of ice-cold concentrated $\mathrm{H}_{2} \mathrm{SO}_{4}(18 \mathrm{M})$ was added and the solution in the wells was stirred manually with a plastic spatula to obtain an equal color development. Standards of L-ascorbic acid (Sigma A 0278) were freshly prepared every day and applied to the plates in amounts of $0,1,2,3,4$, and $5 \mu \mathrm{g}$. Measurements of standards, samples, and blanks were performed in triplicate allowing the assay of one standard curve and 14 samples simultaneously on one plate. The plate was read at $530 \mathrm{~nm}$ with a reference wavelength of $600 \mathrm{~nm}$. Concentrations of total ascorbate were calculated after subtraction of respective blanks. The interassay variability of the procedure was less than $8 \%$ and the intrassay variability was below $5 \%(n=12)$. The method allowed the reliable measurement of about $0.1 \mu \mathrm{g} \cdot \mathrm{well}^{-1}$.

\section{Statistics}

All data sets were analyzed for normal distribution with the KolmogorovSmirnoff test. Because normal distribution often failed, data were square root transformed allowing the statistical analysis by one-way ANOVA. Multiple comparison was performed with the StudentNewman-Keuls procedure. The significance level was set at $p<0.05$.

Nonlinear regression between GSI and ascorbate concentrations in the gonads of prespawning individuals was calculated with the dataanalyzing computer program Prism (GraphPad Inc., San Diego, Calif.). The relationship between both values was sufficiently described by a one-phase exponential decay according to the general equation

$$
\text { (1) } y=\operatorname{span} \cdot \mathrm{e}^{-k \cdot x}+\text { plateau }
$$

Additionally, we investigated whether or not the ascorbate concentration changed due to a simple "dilution" process following the reciprocal equation

(2) $y=b \cdot x^{-1}$

The value $b$ represents the "initial" ascorbate concentration at the lowest GSI ( 1.0 in females and 0.1 in males) calculated by eq. 1 . The goodness of both fits was compared after calculating the sum of squares.

\section{Results}

\section{Gonad maturation and reproductive cycle}

During the summer, the GSI remained at a relatively low level in both sexes. An increase of ovary and testes weight, respectively, was first recorded in October and November (Table 1). The growth of the ovaries continued until February when they reached maximum GSI (16.3 in February 1994). Ovaries from individual animals occasionally exceeded $20 \%$ of carcass weight. The spawning period, characterized by the decrease of the GSI due to the release of eggs, began in February-March and continued until April. In the subsequent postspawning period (May and June), gonad tissue was resorbed. The GSI of 
Fig. 1. Concentrations of ascorbate in dab ( $a$ ) ovaries and $(b)$ testes during the annual cycle (means $\pm 95 \% \mathrm{CI}, n=6-14$ ). The spawning period is indicated by bold lines. Different letters indicate significant differences between sampling periods $(p<0.05$, ANOVA).
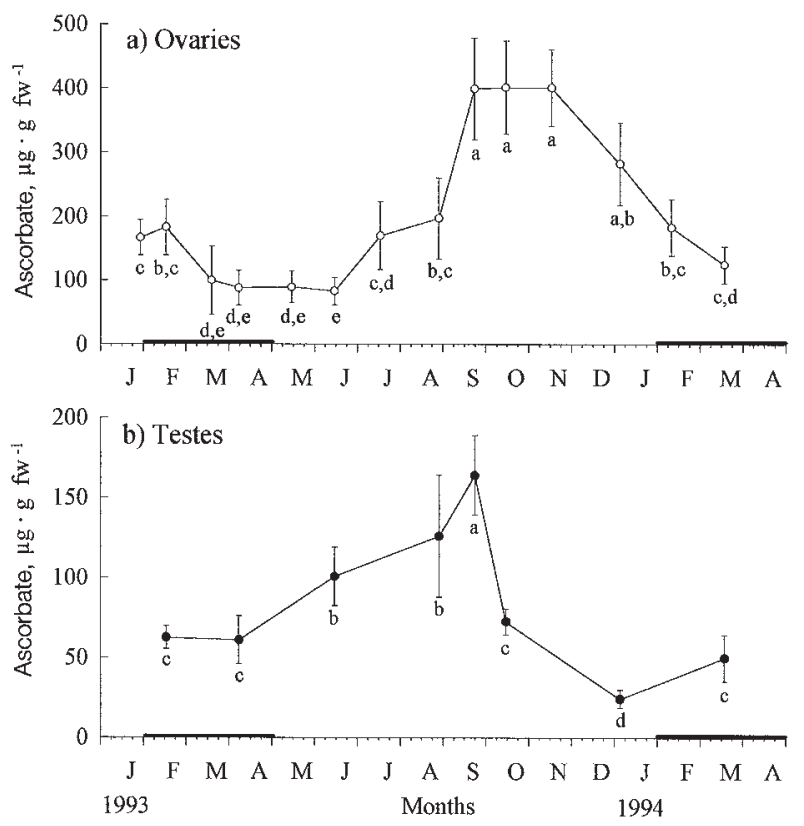

the females fell significantly between March and June and reached lowest seasonal values during the resting period.

The GSIs of male dab were significantly lower on every sampling date of the reproductive cycle than those of female dab. Resting levels were 0.2-0.4. Maximum GSI did not exceed 3.0. A statistically significant increase in gonad weight was first observed between September and October, 1 month earlier than in females. The GSIs reached the maximum in January. After spawning, a significant decrease was evident between January and April.

Based upon the GSI of either sex, the reproductive cycle was classified into four periods (Table 1). The beginning of the spawning period was defined by the maximum of female GSI and appeared in both years in February.

\section{Ascorbate concentrations in the ovaries and testes}

In the ovaries, the lowest ascorbate concentrations of 80 $100 \mu \mathrm{g} \cdot \mathrm{g}$ fresh weight $(\mathrm{fw})^{-1}$ were determined in late spring (Fig. 1), which corresponded to the late spawning and postspawning period. Between June and July, the early resting period, the ascorbate concentrations increased significantly. The increase continued until October, when a maximum of $400 \mu \mathrm{g} \cdot \mathrm{g} \mathrm{fw}^{-1}$ was reached. During the prespawning period in late fall and winter the concentrations decreased continuously to reach the lowest seasonal values again in spring after spawning.

In the testes, the concentrations of ascorbic acid were distinctly lower than in female gonads and ranged between 20 and $170 \mu \mathrm{g} \cdot \mathrm{g} \mathrm{fw}^{-1}$. The lowest concentrations appeared during the prespawning and spawning period. Thereafter, concentrations increased continuously and reached a maximum in September. Subsequently the ascorbate concentrations decreased rapidly.
Fig. 2. Total amount of ascorbate per dab (a) ovary and (b) testis during the annual cycle (means $\pm 95 \% \mathrm{CI}, n=6-14$ ). The spawning period is indicated by bold lines. Different letters indicate significant differences between sampling periods $(p<0.05$, ANOVA).
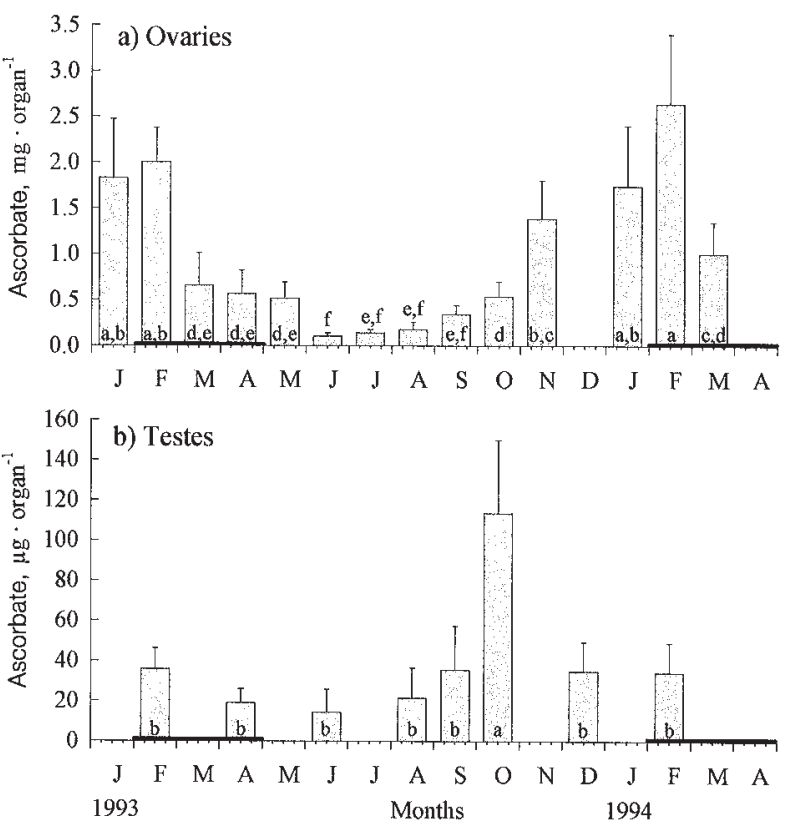

This course coincided with the onset of testis maturation and the most rapid weight increase (Table 1).

Total amount of ascorbate in the ovaries and the testes The absolute amount of ascorbate in the gonad was calculated by multiplying the concentrations by the organ weight. In females, ascorbate peaked during the onset of spawning (Fig. 2a) and closely followed the seasonal course of the GSI. The high values in February significantly exceeded those from the late spawning to late resting period (March-October). The lowest seasonal values were found during the summer. The maturation of the gonads was paralleled by a continuous increase of ascorbate deposition.

In males, ascorbate deposition peaked in October, which coincided with the onset of testis growth (Fig. 2b). During other periods of the reproductive cycle the amounts were constantly low and did not differ significantly.

\section{Ascorbate in relation to the GSI during the prespawning period}

In the ovaries, ascorbate concentrations were inversely correlated with the GSI during the prespawning period (Fig. 3). The ascorbate concentrations decreased to about $30 \%$ of maximum values when the GSI exceeded a value of 10 . The concentrations were always higher than would be expected as a result of "dilution" due to ovary mass increase. The hypothetical dilution curve did not significantly fit the data when the initial value was set at 557.7 for a GSI of 1.0.

In males, also, a significant inverse correlation was found between the GSI and the ascorbate concentration. A rapid decrease was observed as soon as the maturation of the testes began and thus the GSI increased (Fig. 4). Specimens with a GSI of more than 0.4 exhibited only about $50-100 \mu \mathrm{g} \cdot \mathrm{g} \mathrm{fw}^{-1}$, 
Fig. 3. Correlation between the GSI and concentrations of ascorbate in dab ovaries during the prespawning period. The equation parameters refer to the solid line. The broken line indicates the hypothetical course of exponential decrease as a result of dilution when initial values were set to 557.7 at a GSI of 1.0.

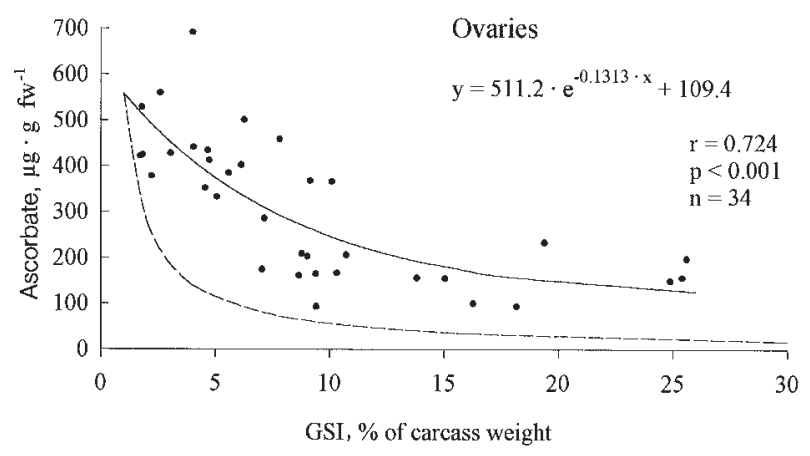

corresponding to $25 \%$ of the initial concentration at the beginning of testis maturation. Further increase in testis weight, however, had no influence on ascorbate concentrations, which remained at a constant level. Similar to females, the exponential decrease model did not fit significantly when the initial value was set at 177.0 at a GSI of 0.1 .

\section{Discussion}

Most studies on the significance of vitamins in fish physiology deal with aquaculture aspects such as optimum growth, health, and reproduction. In this respect, a number of investigations were carried out on fish kept in cages or tanks. However, in addition to laboratory investigations, which at least partly allow the control of experimental conditions, a valuable source of information on the natural conditions and thus a reference for physiological requirements can be obtained from field investigations. Data on ascorbate levels from marine fish species are comparatively limited. Therefore, we performed this seasonal investigation on the marine flatfish species dab.

Dab are the most abundant fish species in the southern North Sea (Sahrhage 1964, 1967) with a biomass of 2.1 million tonnes (Daan et al. 1990) and a high fecundity. The numbers of eggs depend on the age and the size of the fish and can range between 30000 in first spawners $(12.5 \mathrm{~cm})$ and 1 million in 30-cm-long females (Bohl 1957). The onset of spawning varies regionally, starting earlier in the year in the south and later in the north of the area of occurrence. As a measure of the reproductive cycle, we used the seasonal course of the GSI. This allowed us to distinguish the main reproductive periods. The increase in ovary weight was observed in fall (OctoberNovember) and the onset of the spawning period was determined to be the late winter and early spring (February-April). This is in accordance with the observations of Bohl (1957) who determined that the main spawning activity of dab in the German Bight was in March. Similar to our results, Htun-Han $(1978 a, 1978 b)$ reported a short and precise spawning season for dab in the southern North Sea. Dab are considered to be serial spawners (Bohl 1957). The spawning period of individuals is estimated not to exceed 6 weeks (Htun-Han 1978a). The eggs to be spawned in one season develop synchronously (Htun-Han 1978a). Because two distinctly different developmental stages of oocytes (small and yolkless, large and yolked)
Fig. 4. Correlation between the GSI and concentrations of ascorbate in dab testes during the prespawning period. The equation parameters refer to the solid line. The broken line indicates the hypothetical course of exponential decrease as a result of dilution when initial values were set to 177.0 at a GSI of 0.1 .

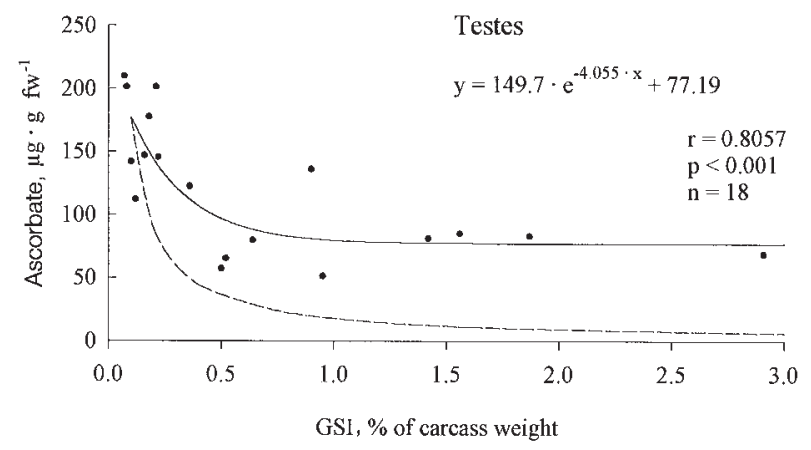

can be distinguished towards the spawning season, the overall duration of oogenesis seems to exceed 1 year (Htun-Han $1978 a$ ). The maturation of the testes paralleled that of the ovaries. However, the growth of the testes started about 1 month earlier than the growth of the ovaries. This observation is in accordance with Bohl (1957) and Htun-Han (1978b). It reflects the successful reproduction strategy: males mature earlier than females and therefore are ready to fertilize the eggs as soon as the first spawnings occur. The postspawning period was determined to be May and June. During that time the gonads redeveloped and remained in a state of resting until the following prespawning period in fall.

A general overview of the results reveals that the levels of ascorbic acid followed the reproduction cycle and exhibited a characteristic seasonal course in both sexes. Except during the late postspawning period, the ascorbate concentration in females was significantly higher $\left(80-400 \mu \mathrm{g} \cdot \mathrm{g} \mathrm{fw}^{-1}\right)$ than in males $\left(30-160 \mu \mathrm{g} \cdot \mathrm{g} \mathrm{fw}^{-1}\right)$ on corresponding sampling dates. The concentrations determined here in dab ovaries correspond to ascorbate concentrations in another marine fish species, Atlantic cod (Gadus morhua) (Sandnes and Braekkan 1981). Similar sexual differences but lower ascorbate concentrations were determined in crucian carp (Carassius carassius) by Seymour (1981) and in Arctic char (high-mountain charr) (Salvelinus alpinus) by Dabrowski (1991); both are freshwater species.

A detailed analysis of the separate reproductive periods reveals slight differences in the annual ascorbate course between the sexes. The lowest ascorbate levels occurred in females during the late spawning and the postspawning period whereas in males the concentrations had already increased again during that time. This shift probably reflects the previously mentioned shift of the reproductive cycle indicated by the GSI. In the following discussion, we will focus on females.

After completion of spawning, ovarian tissue and atretic follicles are generally resorbed to prepare the organs for the next reproductive cycle. During the subsequent resting period, a strong increase in ascorbate concentration was already evident. Although the concentrations rose four to fivefold, this increase was not accompanied by a significant net deposition of ascorbate into the ovaries (Fig. 2). Nevertheless, this increase in concentration indicates a strong metabolic ability to accumulate ascorbate. The ability to accumulate ascorbate 
further increased at the onset of ovarian growth during the prespawning period.

An important function of ascorbate is involvement in collagen formation (Hamilton et al. 1981; Sato et al. 1982). The highest collagen synthesis rates in the ovaries can be expected during the period of most intensive tissue production by cell division, which again can be expected during the first months of ovary maturation. This period corresponded to the highest ascorbate concentrations in the ovaries, supporting a significance in tissue growth due to collagen formation during that period of ovary maturation.

During the prespawning period, the net deposition increased threefold towards the end of the prespawning season. Conversely, the tissue concentration decreased at this time due to the rapidly growing ovary. This decrease may be directly related to ovary mass increase and therefore reflects a dilution process. Nevertheless, individual values remained higher than would be expected as a result of this dilution effect (Fig. 3). Because teleost fish are not able to synthesize ascorbate (Moreau and Dabrowski 1996), it might be transferred from other organs into the ovary (Dabrowski 1991). However, a comprehensive investigation on ascorbate levels in different tissues could not be carried out within this study. A supporting function of the liver can be suggested. Liver ascorbate concentrations were relatively low, ranging below $50 \mu \mathrm{g} \cdot \mathrm{g} \mathrm{fw}^{-1}(\mathrm{R}$. Saborowski, unpublished data). Nevertheless, extremely low values, $5 \mu \mathrm{g} \cdot \mathrm{g} \mathrm{fw}^{-1}$, in female livers during the spawning season seem to indicate a depletion as a possible result of transfer into other organs. At the end of the spawning season, both ascorbate concentrations and ovary ascorbate deposition decreased drastically. A high amount of ascorbate is shunted from the ovary tissue into the maturing follicles, as shown by Seymour (1981) in intraovarian eggs of the crucian carp. In $\mathrm{dab}$, this sharp decrease in ovarian ascorbate is also likely related to its transfer into the eggs followed by their release. Accordingly, the ovary seems to act as a storage organ that accumulates ascorbate and transfers it into the eggs to provide the growing embryo with this essential vitamin.

Compared with the ovaries, concentration and net deposition of ascorbate into the testes were low. In particular, the net deposition was lower by a factor of about 25 in males than in females. This is clearly due to the relatively small size of the testes. However, as in females, the concentration of ascorbate continuously increased after spawning to reach the highest concentrations in September at the beginning of the prespawning period. The sharp decrease between September and October which continued until the end of the prespawning season is related to a mass increase of the testes. Nevertheless, as in females, concentrations remained higher than would be expected as a result of dilution (Fig. 4). The highest net deposition of testicular ascorbate appeared at the beginning of the prespawning period. In particular, the beginning of the prespawning period is reflected by a high cellular activity due to the mitotic multiplication of spermatogonia and thereafter by the meiotic division of spermatogonia to primary and secondary spermatocytes and spermatides (Htun-Han 1978b). Fish sperm quality might be positively affected by ascorbate supplementation, as found in humans (Dawson et al. 1987). In fish, there is some indication for impaired sperm quality associated with ascorbate deficiency (Ciereszko and Dabrowski 1995).
Another possible function of ascorbate in reproductive physiology might be related to steroid metabolism. In amphibian testes, the administration of ascorbate and dehydroascorbate stimulates the activity of enzymes involved in androgen biosynthesis (Biswas 1969; Biswas and Deb 1970). However, the significance of ascorbate in fish steroid synthesis has not been sufficiently investigated. If ascorbate is involved in sex steroid synthesis, this process is probably independent of high concentration because at the period where highest serum sex steroid titers can be expected (January and February), ascorbate concentrations were comparatively low.

The sex-specific differences and variations of ascorbate in the gonads within the annual course of the reproduction cycle also point to a generally different demand for ascorbate between sexes. This demand must be covered by the diet. A previous investigation (Saborowski and Buchholz 1996) has shown that female dab feed more intensively and therefore store more nutrients, and likely also more vitamins, than do male dab. Furthermore, females retain a high nutritive state until winter, the prespawning period, while the feeding activity of males is already decreasing. This difference in the feeding habits may explain how female dab are able to provide high amounts of ascorbate for reproductive purposes.

In conclusion, sexual differences and seasonal courses in the ascorbate levels in dab gonads are closely related to the specific function of the organs. The ovaries provide high ascorbate levels to be released with the eggs for the benefit of the fry. The testes do not have to release high amounts of ascorbate, but need to retain a certain quantity during the important phases of spermatogenesis. In both organs, however, ascorbate is related to cell division and (or) growth, either in the gonad itself or in the target, i.e., the embryo. Accordingly, the properties of ascorbate as antioxidant in lipid and membrane protection as well as DNA protection seem to be important.

Future work should investigate the sources of ascorbate in the diet of dab, marine macrozoobenthos, and the distribution of ascorbate in different tissues and organs as well as the metabolic ability to accumulate ascorbate in the ovaries.

\section{Acknowledgements}

We acknowledge the help of the technical staff of the participating institutes. This work was supported by the GermanCanadian Science and Technology Cooperation Agreement under project No. KAN-AQ30 (piscine ecotoxicology).

\section{References}

Biswas, N.M. 1969. $\Delta^{5}-3 \beta$-Hydroxysteroid dehydrogenase in toad testis: synergistic action of ascorbate and luteinizing hormone. Endocrinology, 85: 981-983.

Biswas, N.M., and Deb, C. 1970. In vitro studies on the effects of ascorbic acid and dehydroascorbic acid on $\Delta^{5}-3 \beta$-hydroxysteroid dehydrogenase in toad testis. Endocrinology, 87: 170-173.

Bohl, H. 1957. Die Biologie der Kliesche (Limanda limanda L.) in der Nordsee. Ber. Dtsch. Wiss. Komm. Meeresforsch. 15: 1-57.

Carr, R.S., Bally, M.B., Thomas, P., and Neff, J.M. 1983. Comparison of methods for determination of ascorbic acid in animal tissues. Anal. Chem. 55: 1229-1232.

Chow, C.K. 1991. Vitamin E and oxidative stress. Free Radical Biol. Med. 11: 215-232. 
Ciereszko, A., and Dabrowski, K. 1995. Sperm quality and ascorbic acid concentration in rainbow trout semen are affected by dietary vitamin C: an across season study. Biol. Reprod. 52: 982-988.

Daan, N., Bromley, P.J., Hislop, J.R.G., and Nielsen, N.A. 1990. Ecology of North Sea fish. Neth. J. Sea Res. 26: 343-386.

Dabrowski, K. 1977. The L-ascorbic acid content in silver-bream's (Vimba vimba L.) organs. Pol. Arch. Hydrobiol. 24: 569-573.

Dabrowski, K. 1991. Ascorbic acid status in high-mountain charr, Salvelinus alpinus, in relation to the reproductive cycle. Environ. Biol. Fishes, 31: 213-217.

Dabrowski, K., and Blom, J.H. 1994. Ascorbic acid deposition in rainbow trout (Oncorhynchus mykiss) eggs and survival of embryos. Comp. Biochem. Physiol. A Comp. Physiol. 108: 129-135.

Dawson, E.B., Harris, W.A., Rankin, W.E., Charpentier, L.A., and McGanity, W.J. 1987. Effects of ascorbic acid on male fertility. Ann. N.Y. Acad. Sci. 498: 312-323.

Halver, J.E. 1989. The vitamins. In Fish nutrition. Edited by J.E. Halver. Academic Press, San Diego and London. pp. 32-109.

Hamilton, S.J., Mehrle, P.M., Mayer, F.L., and Jones, J.R. 1981. Mechanical properties of bone in channel catfish as affected by vitamin $\mathrm{C}$ and toxaphene. Trans. Am. Fish. Soc. 110: 718-724.

Hapette, A.M., Coombs, S., Williams, R., and Poulet, S.A. 1991. Variation in vitamin C content of sprat larvae (Sprattus sprattus) in the Irish Sea. Mar. Biol. 108: 39-48.

Htun-Han, M. 1978a. The reproductive biology of the dab Limanda limanda (L.) in the North Sea: seasonal changes in the ovary. J. Fish Biol. 13: 351-359.

Htun-Han, M. 1978b. The reproductive biology of the dab Limanda limanda (L.) in the North Sea: seasonal changes in the testis. J. Fish Biol. 13: 361-367.

Mahajan, C.L., and Agrawal, N.K. 1980. Nutritional requirement of ascorbic acid by Indian Mayor carp, Cirrhina mrigala, during early growth. Aquaculture, 19: 37-48.

Moreau, R., and Dabrowski, K. 1996. The primary localization of ascorbate and its synthesis in the kidneys of acipenserid (Chondrostei) and teleost (Teleostei) fishes. J. Comp. Physiol. B Biochem. Syst. Environ. Physiol. 166: 178-183.

Saborowski, R., and Buchholz, F. 1996. Annual changes in the nutritive state of North Sea dab. J. Fish Biol. 49: 173-194.

Sahrhage, D. 1964. Über die Verbreitung der Fischarten in der Nordsee. Teil I, Juni-Juli 1959 und Juli 1960. Ber. Dtsch. Komm. Meeresforsch. 17: 165-278.

Sahrhage, D. 1967. Über die Verbreitung der Fischarten in der Nordsee. Teil II, Januar 1962 und 1963. Ber. Dtsch. Komm. Meeresforsch. 19: 66-179.

Sandnes, K., and Braekkan, O.R. 1981. Ascorbic acid and the reproductive cycle of ovaries in cod (Gadus morhua). Comp. Biochem. Physiol. A Comp. Physiol. 70: 545-546.

Sandnes, K., Ulgenes, Y., Braekkan, O.R., and Utne, F. 1984. The effect of ascorbic acid supplementation in broodstock feed on reproduction of rainbow trout (Salmo gairdneri). Aquaculture, 43: $167-177$.

Sato, M., Kondo, T., Yashinaka, R., and Ikeda, S. 1982. Effects of dietary ascorbic acid levels on collagen formation in rainbow trout. Bull. Jpn. Soc. Sci. Fish. 48: 553-556.

Sato, M., Yoshinaka, R., Kuroshima, R., Morimoto, H., and Ikeda, S. 1987. Changes in the water soluble vitamin contents and transaminase activity of rainbow trout eggs during development. Bull. Jpn. Soc. Sci. Fish. 53: 795-799.

Seymour, E.A. 1981. Gonadal ascorbic acid and changes in the level with ovarian development in the crucian carp, Carassius carassius (L.). Comp. Biochem. Physiol. A Comp. Physiol. 70: 451-453.

Stebbing, A.R.D., Dethlefsen, V., Addison, R.F., Carr, M., Chapman, P.M., Cofino, W.P., Heip, C., Karbe, L., Moore, M.N., and Vethaak. A.D. 1992. Overall summary and some conclusions from the Bremerhaven workshop. Mar. Ecol. Prog. Ser. 91: 323-329. 